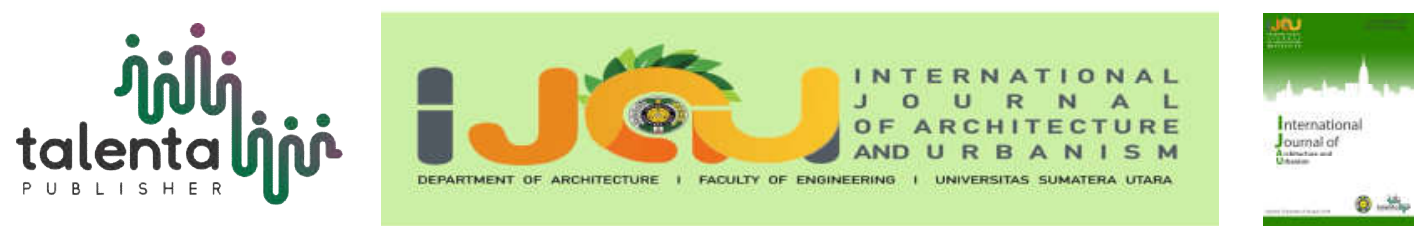

\title{
East Binjai Shopping Center and Recreation
}

\author{
Firman Eddy $^{I^{*}}$, T. Hasyiral Haikal \\ ${ }^{1}$ Department of Architecture, Universitas Sumatera Utara, Medan, Indonesia
}

\begin{abstract}
Binjai is one of the cities included in the Mebidangro development project which includes Medan City, Binjai City, Deli Serdang Regency, and Karo Regency. Strategic location located on the road cross Sumatera make Binjai City a prosperous city in its development. The economic condition of the city of Binjai in the previous few years continues to increase, in the sector of Large and Retail Trade. Based on survey results, the city of Binjai still needs a center of excellence and recreational facilities such as cinemas and eating places to improve the economic quality of the city. The adhesive of East Binjai Shopping and Recreation Center is expected to meet those needs. The hot temperature of the city of Binjai becomes the designer's choice of theme "Green Architecture" as the design theme. It is considered very suitable for heat temperature to the building. A design approach that carries the theme of Green Architecture can create environmentally friendly buildings. Implementation of this theme is also useful to save the operational costs of the building.
\end{abstract}

Keyword: mall, shopping center, recreation, green architecture

\section{Introduction}

Binjai City is one of the cities in the province of North Sumatra, Indonesia. Binjai is one of the areas in the Mebidangro development project which includes Medan City, Binjai City, Deli Serdang Regency, and Karo District. Binjai is located $22 \mathrm{~km}$ west of the provincial capital of North Sumatra, Medan and is connected by the Sumatra Highway. This strategic location has the potential to make Binjai a prosperous city in its development. Based on data from Statistical Center Hub Binjai City, population growth rate in Binjai City has increased. This condition is in line with the economy of the city of Binjai which is considered stable in recent years. This high population growth automatically led to high levels of demand for city facilities and utilities.

Based on the survey results, it is said that the city of Binjai still needs a shopping center as many as eight units and recreational facilities such as cinemas and eating places to improve the quality of the economy of the City [3]. This makes sense, given the mall can provide an increase in income of a city in the form of taxes, because of economic activity there.

\footnotetext{
*Corresponding author at: Department of Architecture, Faculty of Engineering, Universitas Sumatera Utara,

Jalan Perpustakaan Gedung J07, Medan 20155, Indonesia

E-mail address: rechvidimaz@yahoo.com
} 


\section{Literature Review}

\section{Object Description}

East Binjai Shopping and Recreation Center is a mall that embraces the open mall concept with the theme "Green Architecture."This type is formed by closing the streets and then developed into a pedestrian or plaza street equipped with trees, fountains, sitting groups, and other appendages, such as sculptures or garden lights [4]. This design includes architectural design, structural design, circulation design, and utility design based on function, shape, user activity, and related government regulations. This discussion is based on analyzes derived from literature studies and comparative studies.

\section{Location and Site}

Location of East Binjai Shopping and Recreation Center is located East Binjai district, Binjai Kota. East Binjai District is one of the areas in Binjai City which has an area of about 21.70 $\mathrm{km} 2$, while the city of Binjai itself has an area of $90.23 \mathrm{~km} 2$. The location of the design is on the DanauMakalona Street, District of East Binjai, which has a land area of 50,000 m2 (Figure 1).

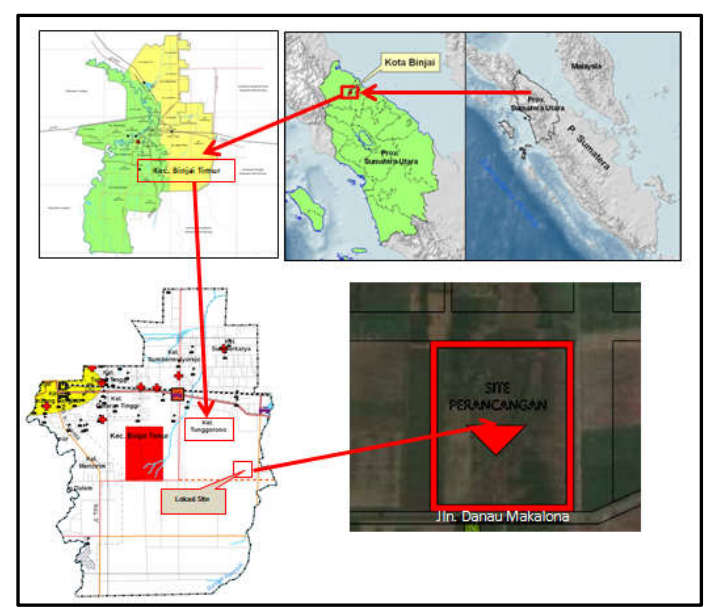

Figure 1. Location and Site

\section{Theme Review}

Green Architecture is an environmentally sound architecture that is based on concern about the conservation of the global natural environment with an emphasis on energy-efficient, sustainable and holistic approaches [1]. 'Green' can be interpreted as a sustainable, earthfriendly, and high-performance building. Architectural indications are referred to as 'green' when associated with architectural practices such as the use of renewable resources, passiveactive solar photovoltaic (solar cell solar cells), plant roofing techniques, rain-fed gardens, compressed for pavement areas, etc. The concept of 'green' can also be applied to the reduction of energy use (e.g., electrical energy), low energy house and zero energy building by 
maximizing the building envelope. Use renewable energy such as solar, biomass, and waste treatment into energy are also worth taking into account [2].

\section{Methodology}

The research method used in the design of the Shopping and Recreation Center of East Binjai is a qualitative research method, the research method used to examine the condition of natural objects as opposed to the experiment. Qualitative research is a study aimed at understanding social reality. In this qualitative research, there are several approach method that is done by field survey, participant observation, literature study, and case study. The reference of design site selection is based on Spatial Planning (RTRW) ${ }^{1}$ of Binjai City which has been reviewed. Based on the city space structure development plan, it is explained that the design location is in the area that will be functioned for the development of an industrial area, government center, and the center of growth and service of the city.

\section{Result and Discussion}

\section{User analysis}

Users of activities in the East Binjai Shopping and Recreation Center consist of visitors, tenants, managers, and services. Visitors are parties to the East Binjai Shopping and Recreation Center, which is divided based on certain considerations such as classes, origins, and services that conduct shopping and leisure activities. Tenants are parties who rent retail-retail contained in buildings to sell their goods and services to visitors who come. Managers are those who manage the administrative and operational activities that are divided into two levels, namely the Leader (Director) and the Head of Section. Service is the party who perform the activities of building services such as technical problems, cleanliness, security, utilities, pantry, and warehousing.

\section{Site Analysis}

Location of East Binjai Shopping and Recreation Center located on DanauMakalona Street, East Binjai District, North Sumatra. Precisely in the empty Land Area which is the former owner of PTPN2 ${ }^{2}$. Based on City's Spatial Planning, East Binjai District is not intended for centers of trade and services. However, there is a developer (PT Duraman Lestari) who already has a development plan in East BinjaiSubdistrict, and the shopping center is one of the development plans of the developer. The land on this project has an area of $5 \mathrm{Ha}$. The primary arterial street is 30 meters, has a maximum $\mathrm{KDH}^{3}$ of $20 \%$ and a $\mathrm{KDB}^{4}$ of $40-70 \%$.

Conditions at the current design site consist of vacant land and houses. The location area is located on the edge of Danau Makalona Street and quite far from the nearest residential area.

\footnotetext{
${ }^{1}$ RTRW (Rencana Tata Ruang Wilayah)

${ }^{2}$ PTPN 2 (PT Perkebunan Nusantara 2)

${ }^{3} \mathrm{KDH}$ (Koefisien Dasar Hijau)

City's Spatial Planning

${ }^{4} \mathrm{KDB}$ (Koefisien Dasar Bangunan)

The State Plantation Company 2

: Green Space Coverage Ratio

: Building Coverage Ratio
} 
Achievements to the design site are relatively fast, at the time of achievement of 15 minutes from downtown Binjai using public transportation or private vehicles. The location is also not far from other districts in the city of Binjai with a maximum distance of 20 minutes (South Binjai) using public transportation or private vehicles.

According to spatial planning (RTRW) of East Binjai, the area is designated as the development of an industrial area, government center, and growth center\&service of the city. In the analysis of land use, the circumstances surrounding the area surrounded by the former area of paddy fields and sweet potato fields, residential areas and there is also a cemetery near the design site.

\section{Theme Implementation Analysis}

The analysis of the theme Penerpaan on the design of Shopping and Recreation Center East Binjai more adjust to the climate conditions of the city of Binjai. The city of Binjai includes a fairly hot area, relatively low rainfall, which is an average of $1100 \mathrm{~mm}$ per year, so almost every year experiencing a long summer. Based on the data, according to the designer, the concept of an open mall with the theme of green building is very suitable to anticipate the heating temperature in buildings. This building will apply the green building theme by putting a lot of openings in the building to utilize the natural airing in the building, the use of glass material to utilize natural lighting in buildings, as well as the use of environmentally friendly building materials, such as the use of wood to absorb solar heat, mirror glass to reflect sunlight, and also the use of paving blocks to allow water to flow to the lower layer of soil. Implementation of green building theme is also useful to save the operational cost of the building.

\section{Basic Concept}

Based on the background and problems faced in the design of this mall, the concept of "Environmentally Friendly" is used as the basis for its design. This mall will be a mall-based "open mall." As it is known that the global problems facing the earth today are global warming and the destruction of natural resources. Therefore, this building in the design is expected to reduce adverse impact on the surrounding environment. With that shopping center should also promote the convenience of existing users around. One of the dominant problems in the tropics is the amount of solar radiation that affects the conditions of space in the building and the comfort of the user. In this case, the role of structures and roof of the building becomes important in getting around reduction of solar radiation (Figure 2). 


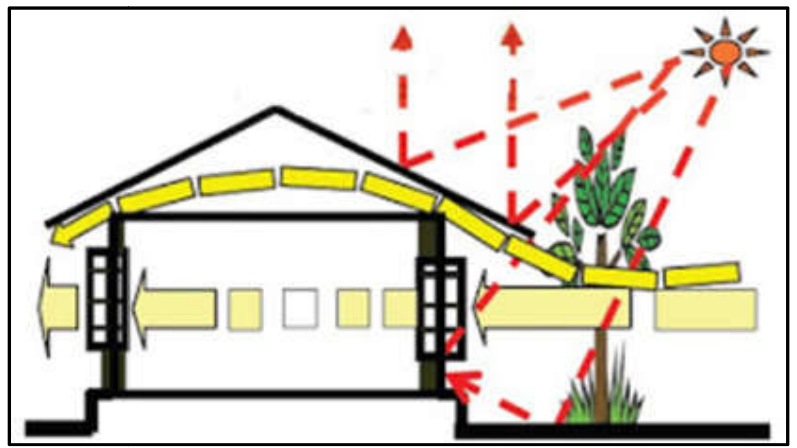

Figure 2. Natural Light and Air Application

\section{Concept of Layout}

Location of the design with an area of $\pm 50,000 \mathrm{~m} 2$ located on DanauMakalona Street, East Binjai has a Set Back Building (GSB) $)^{5}$ of $12 \mathrm{~m}$ from the main street. Site divided into several zoning that is the mass of the main building, mechanical building with Building Coverage Ratio (KDB) $40 \%-70 \%$ or $\pm 25.000 \mathrm{~m} 2$ and green open space $15-40 \%$ from land or $\pm 4,000 \mathrm{~m} 2$ (Figure 3). Outside spatial arrangement on site-oriented site processing around the main mass that functioned as parking area and park. The parking area is arranged on the four sides of the building. This is because the hospital parking needs to serve certain functions. At the entrance there are parks, drop off areas, fountain, and circulation in and out of vehicles (Figure 4).

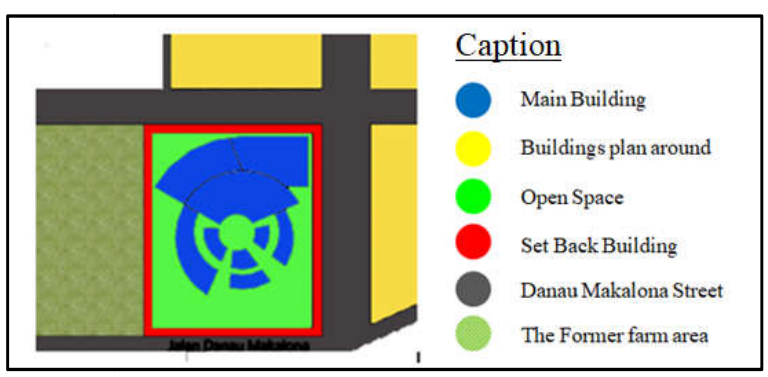

Figure 3. Site Zoning

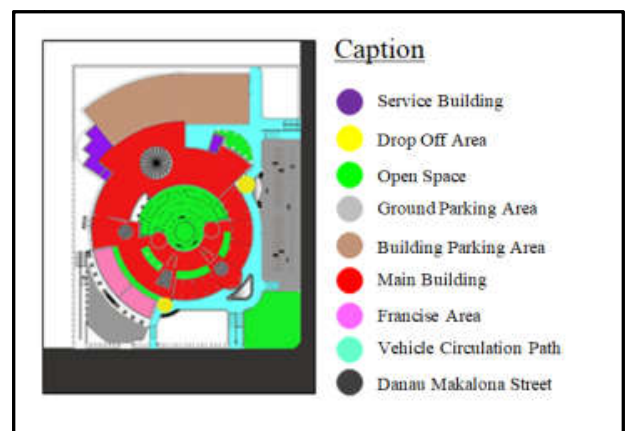

Figure 4. Outer Space Zoning

\footnotetext{
${ }^{5}$ GSB (Garis Sempadan Bangunan) : Set Back Building
} 


\section{The concept of Mass and Countenance}

The mass of the building overlooks the main of Danau Makalona Street and the Ringroad 2 (plan) street. Therefore the building faces east and south. Parts of the building that has the direction of the east get more sunlight in the morning which certainly does not affect the comfort of visitors because the mall operational hours start at around 11:00 pm. While the southern-facing building certainly has its advantages because it is not too exposed to sunlight. However, sunlight is also needed to help save the use of electrical energy during the day in the building. In addition to the east and south direction, there are several parts of the building facing to the west and directly exposed to the afternoon sun until the afternoon. This can be trickled by the processing of building forms and the use of the right material to maximize natural lighting without reducing the user's comfort. Building this shopping center and recreation East Binjai uses the formation of a circle as the formation of the main mass. By using a circle shape, the light that enters the building can be more evenly distributed. However, building facades must use glass material that has a thickness sufficient to heat not too permeated to the inside of the building. Do not also forget the use of secondary skin to minimize the heat of the incoming sun revival (Figure 5).

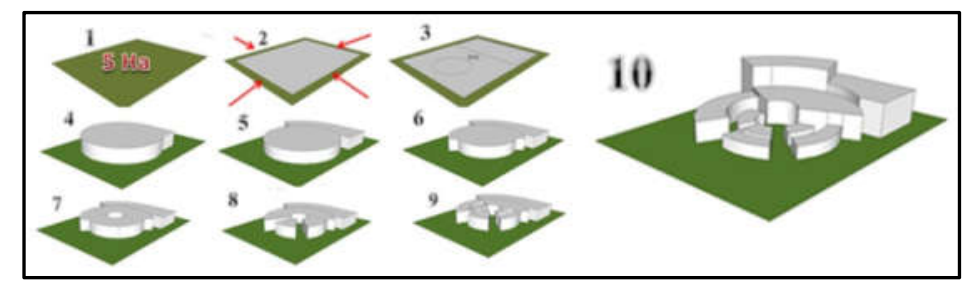

Figure 5. Building Mass Changes

\section{Concept of circulation}

In the design of the site, there is two main entrance, which is on the DanauMakalona Street and Ringroad 2 (plan) street. This is done to avoid congestion on each street. For the main entrance is on the Ringroad 2 (plan) street. This path is specified as the only entry point. The line is adjacent to the service car entrance. By going through this entrance, users can drop off and then head for the ground parking lane. While the entrance lane on the side of DanauMakalonastreet allows users to drop off passengers only. On this street, there is also a major service line that allows service vehicles to pass anytime. The design of the parking area design in this building is designed as flexible as possible. This is intended so that users can pass through all the parking lanes without a hitch. So if one parking area is full, users can easily go to another parking area (Figure 6). 


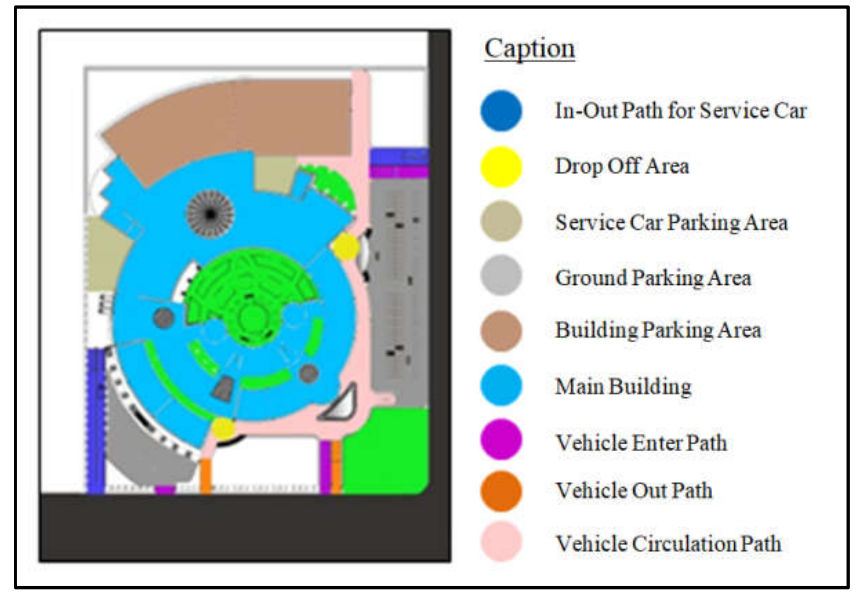

Figure 6. Circulation of Achievement

\section{Space Hierarchy}

The hierarchy of space on the design site begins with Ringroad 2 (plan) street which is the main entrance to the designing tread (Figure 7). The separator between the public spaces and the designing treads is handled by the fence boundary design concept, so it is clear the physical boundary between the public space and the design site.

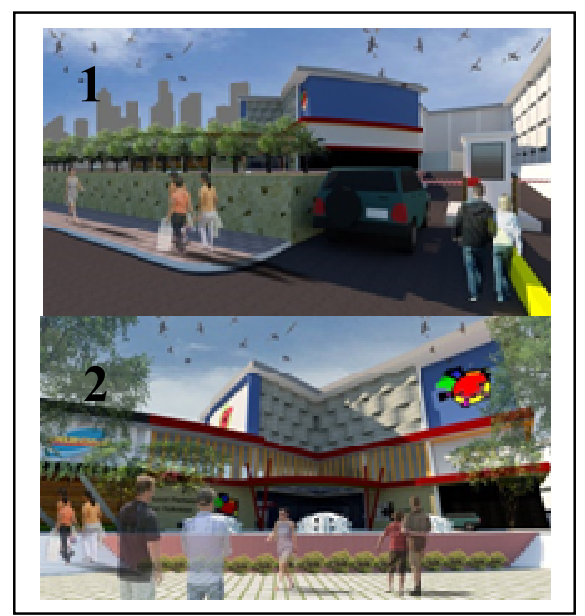

Figure 7. Enter Lane (1) and Main Entrance (2)

\section{Building Design Concept}

East Binjai Shopping and Recreation Center is divided into 3 zones of public, service, and private areas. The public areas include shopping and recreational facilities, such as green open areas, food court, retail-retail, game center, fitness center, and others. Service areas include utility room buildings and visitor services areas such as bathrooms and mosques. The private area consists of administration and management room is part of shopping center manager office.

\section{Building Zoning}

East Binjai Shopping and Recreation Center is divided into 4 zone sections: parking zone, main building zone, main plaza zone, and green open space zone. The parking zone consists of 
ground parking and building parking. The main building zone consists of shopping areas, dining areas, lounging areas, and utility areas (Figure 8). The green space is located in the building and at the corner of DanauMakalona Street-Ringroad 2 street. While the main plaza zone is in the middle of the main building as the center point of the center of this shopping center (Figure 9).

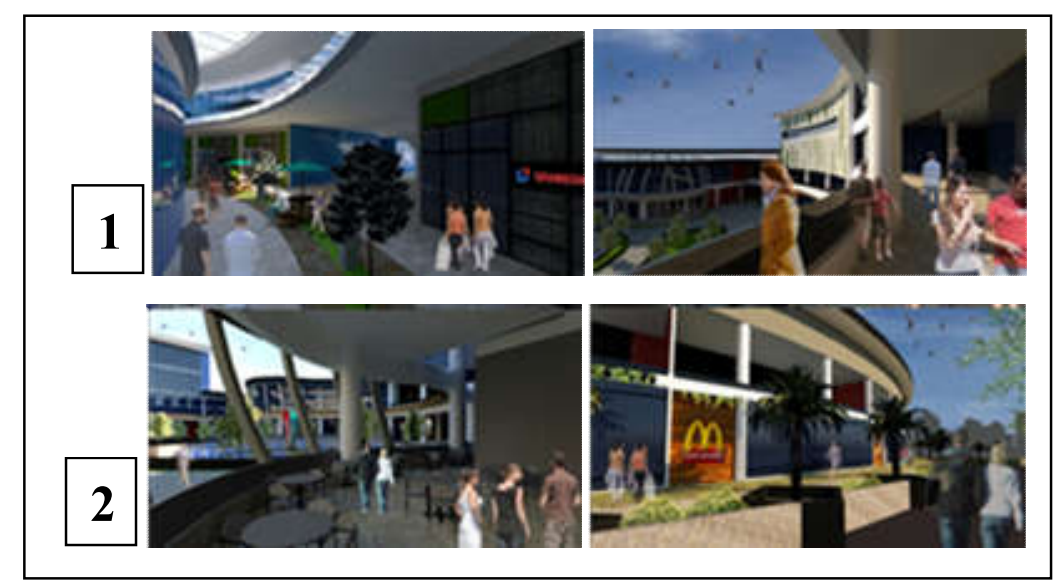

Figure 8. Shopping Area (1), Dining and Lounging Area (2)

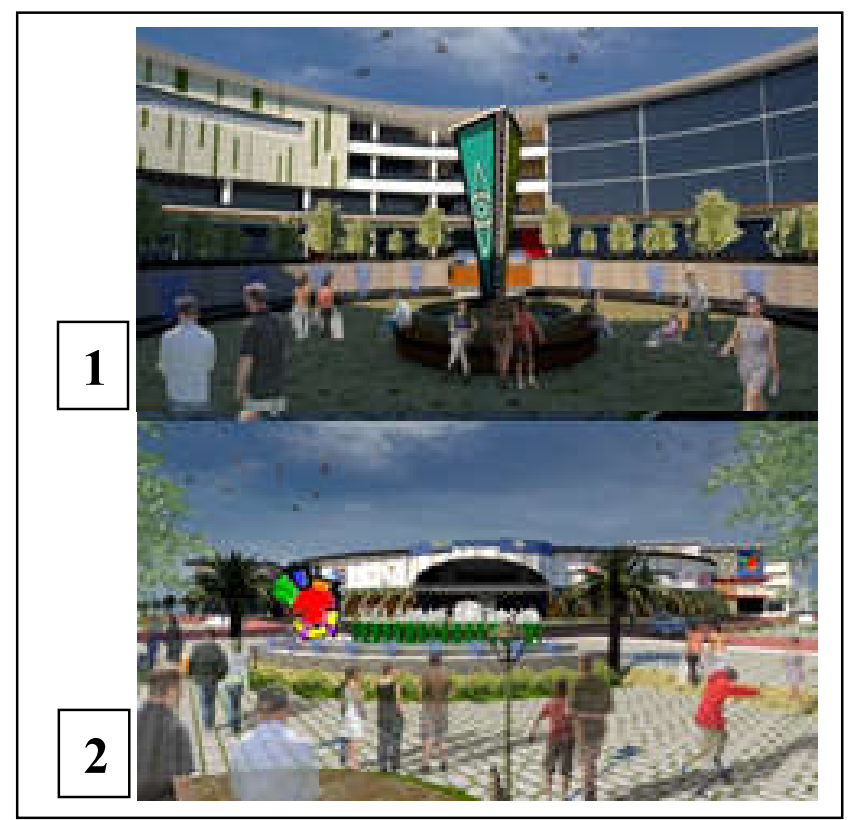

Figure 9. Main Plaza (1) and Open Space at The Corner of the Building (2)

\section{Building Circulation}

East Binjai Shopping and Recreation Center uses two types of circulation namely the horizontal and vertical circulation. The horizontal circulation uses a linear circulation, which is a corridor. While the vertical circulation consists of elevators, escalators, and emergency stairs. 


\section{Structure Design}

The structural system used in the design of shopping and recreation center of East Binjai is the rigid frame system structure, where the structure focuses more on the grid system that supports the function of the spaces within it. The building's grid itself is circular, unlike the grid in general, i.e., square. The combination of cores and columns forms a structure capable of supporting loads on it. And also use the structure, in general, such as; sloof, column, beam, beam ring and dilation. The main building column uses $80 \mathrm{~cm}$ x $80 \mathrm{~cm}$ columns. This building uses boor pile foundation (Figure 10).

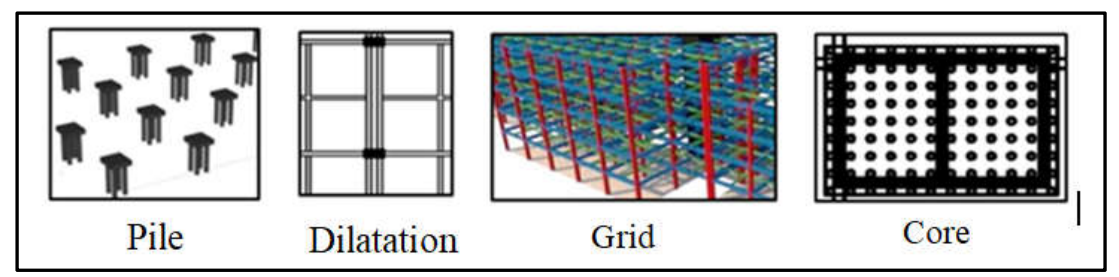

Figure 10. Use of the Structure design

\section{Conclusion}

East Binjai Shopping and Recreation Center is located at Danau Makalona Street, Binjai, North Sumatra. This street is the primary arterial street in East Binjai district. Also, there is a plan of street construction by a team of developers who will be named the street of Ringroad 2. This street will connect East Binjai with Binjai-Medan toll street. The mass form of Binjai Shopping and Recreation Center is a circle with slight modifications. There is a green open space in the middle of the building that serves as a plaza as well as the center point of the building. Also, there are two parking areas, namely ground parking and parking buildings that are expected to accommodate the needs of visitor parking.

The main vehicle entrance for visitors to the East Binjai Shopping and Recreation Center is on the east side of the design site, precisely on the Ringroad 2 street. The entrance line is adjacent to the service lane. The alternate entry point is on the DanauMakalona Street, precisely on the south side of the design site. On the south side, there are also two major exit routes. The main service line is also on the Makalona Lake street. The ground parking area is in front of the main entrance of the building, exactly on the east side. Circulation patterns are designed as flexible as possible to facilitate user access to all corners of buildings, especially parking and drop-offs. For parking of service vehicles, located in the western part of the building, adjacent to the loading dock to facilitate the process of loading and unloading of goods.

\section{Acknowledgment}

This research is part of the requirement to obtain a bachelor's degree in Architecture Department Universitas Sumatera Utara. 


\section{REFERENCES}

[1] Jimmy Priatman. Energy-Efficient Architecture, Paradigma dan Manifestasi Arsitektur Hijau. Surabaya :Universitas Kristen Petra. 2002.

[2] M. Maria. Sudarwani. Penerapan Green Architecture Dan Green Building Sebagai Upaya Pencapaian Sustainable Architecture. Vol 10, No.24 :Universitas Pandanaran. 2012.

[3] Haris Abadsyah. Binjai Shopping Mall : Arsitektur Metafora. Medan : Universitas Sumatera Utara. 2014.

[4] J. D. Chiara \& M. J. Crosbie. Time Saver Standart For Building Types. USA : McGraw Hill Book Co. 1973. 